\title{
The Implications Of Leadership On Narco-Terrorism Policy Management
}

Craig S. Cleveland, Shorter College

Andrew Honeycutt, Shorter College

\begin{abstract}
The purpose of the study was to determine the impact of leadership and managerial decision making within the Drug Enforcement Administration since September 11, 2001. A web based survey questionnaire was used to collect the data. Participants in the study were criminal justice professors from randomly selected colleges and universities located in the southeast and southwest region of the United States. Qualitative and quantitative research methods were used. Each participant was asked to complete a post survey that addressed areas of leadership and decision-making based on opinions and knowledge related to criminal justice. Paired samples $t$ test was used to describe the data. In spite of the survey findings of change in knowledge, skills, and cultural behavior, these changes did not appear to lead to significant differences in determining leadership skills. It is recommended that future studies use a survey sample instrument designed to measure attitudinal dimensions of decision-making among leaders and managers within the Drug Enforcement Administration. One possible recommendation is to utilize a different type of comparison method or instrument that would measure certain dimensions of managerial levels between upper and lower management.
\end{abstract}

\section{STUDY BACKGROUND AND OBJECTIVES}

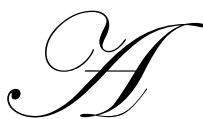

lthough drug trafficking and terrorism has been around for a number of decades, it is only recently that terrorists have formed an alliance with drug traffickers to help fund their organizations by way of trafficking, manufacturing, and transporting drugs. For example, in Afghanistan, the former ruling Taliban built its financial base from heroin trafficking. Hutchinson (2002) stated that "intelligence confirmed a connection between the Taliban and international terrorist Osama bin Laden and the al Qaeda organization being involved in the financing and facilitation of heroin trafficking activities" (p. 1). For the general reader, Afghanistan has always been a major source country for the cultivation, processing, and trafficking of opiate products which produce heroin. Since the September 11, 2001 terrorist attacks, many intelligence reports have surfaced linking terrorists with drug trafficking.

The most important problem facing the DEA today is how to fight drug trafficking and terrorism simultaneously. The leaders within the DEA have to develop strategic decision-making tools in order to stay onestep ahead of narco-terrorist groups. Capable and focused leadership is an important ingredient for effectiveness and success of any organization (Morreale, 2000). The DEA's needs to focus on identifying how terrorist groups transport and distribute their drugs and what money laundering schemes are being used to maintain their operations. The DEA's leadership has to show the public that they are spending a considerable amount of time building multiple linkages between domestic and international organizations. Some of the linkages must be achieved through increased communication, intelligence sharing, technology, enforcement and diplomacy. DEA leaders have to enhance the creative and analytical thinking through the use of tools that are provided to them by Congress. This will give leaders and managers an opportunity to develop other methods of enforcement measures and keep pace with new technology.

This study acknowledges that being part of a management team within the DEA requires quality organizational decision-making initiatives. In order to investigate the style of leadership the DEA exhibits, experts 
in the field of criminal justice should be allowed to form an opinion as to likes or dislikes in managing. In particular, criminology and criminal justice researchers can make a significant contribution by improving the conceptualization, analysis and understanding of the style of leadership and aid in the development of meaningful and informed policy (Kennedy \& Lum, 2003). Often times, criminologists and criminal justice researchers provide insight to policy makers regarding law enforcement strategies, surging crime trends and penal reform.

DEA Administrator Tandy (2003) stated "after 9-11, the redirection of resources placed the responsibility of drug enforcement more squarely on the shoulders of the DEA than ever before" (p. 1). Therefore, the most specific and narrow portion of this literature review will focus on journal articles, documents, court cases, government testimonies and other analyses explicitly examining the leadership and decision making efforts within DEA.

Leadership styles refer to how a leader is able to influence the followers. There are certain characteristics that influence the effectiveness of the leader. Leaders are identified by two distinct leadership styles: transformational leaders and transactional leaders (Bass \& Stogdill, 1990).

Transactional leadership focuses on influencing and motivating the followers through rewards and reprimanding. Transactional leadership consists of four elements: contingent rewards, exceptional management, and management by exception, and laizzez-faire. Contingent rewards are used by transactional leaders to motivate their followers. Contingent rewards refer to exchanging rewards through praising and acknowledging the followers for outstanding performance (Bass \& Stogdill, 1990). Exceptional Management refers to being alert to deception within policies and procedures within the organization in order to take immediate action. Management by exception is providing feedback to correct problems or seeking to identify potential problems. Laissez-faire is non-leadership, it denounces responsibility while diverting decision-making (Bass \& Stogdill, 1990).

Leadership within the Drug Enforcement Administration plays an integral role in communities across America as well as across the globe. The leadership of DEA wants to assure society that drugs will not be tolerated on the streets of America. DEA leaders know that this type of assurance from DEA creates a vision of good public service. Most leaders see their success through the visions they create. Often times, visionary leaders have to make adjustments as to what is the quickest road to take towards achieving a goal. DEA leaders are known to make those types of adjustments to combat drug trafficking, money laundering and now, a new phenomenon called narcoterrorism. Former DEA Administrator Asa Hutchinson (2002) once stated that the "DEA will continue to identify, investigate, and build cases against criminal and terrorist groups involved in drug trafficking wherever they may be found" (p. 2).

Narco-terrorism is a global problem, and with the same areas of the world that have the most difficult problems in terrorism also have the most difficult problems with drug production (Johnson, 2002). Society perceives drug trafficking and terrorism as a destruction to life, liberty and the pursuit of happiness, therefore, the nexus between the two will always be unacceptable. Drug trafficking in source countries, transit countries, and consumer countries, including the United States could contribute to the problems of terror in at least five distinct ways:

- $\quad$ Supplying cash for terrorist operations.

- $\quad$ Creating chaos in countries where drugs are produced, through which they pass, or in which they are sold at retail causing chaos sometimes deliberately cultivated by drug traffickers to provide an environment conducive to terrorist activity.

- Generating corruption in law enforcement, military, and other governmental and civil-society institutions in ways that either build public support for terrorist-linked groups or weaken the capacity of the society to combat terrorist organizations and actions.

- $\quad$ Providing services also useful for terrorist actions and movements of terrorist personnel and material, and supporting a common infrastructure, such as smuggling capabilities, illicit arms acquisition, money laundering, or the production of false identification or other documents, serving both drug-trafficking and terrorist purposes.

- $\quad$ Competing for law enforcement and intelligence attention (Kleiman, 2004, p. 3). 


\section{STUDY METHODOLOGY}

This case study attempted to capture the perspective of DEA leaders and managers during a given time period dating back to September 11, 2001. The researcher e-mailed a survey questionnaire to the randomly selected group of criminal justice professors from a designed web page. Attached with the questionnaire were a solicitation letter of introduction to the researcher and a letter from Dr. Andrew Honeycutt who is committee chair. Upon completion of the questionnaire, the web page automatically recorded the collected data. It is understood that the responses collected through this case study represent only those of a given group of individual respondents.

The case study's respondents consisted of a randomly selected population of 300 criminal justice professors from colleges and universities, also selected at random from southeastern and southwestern regions of the United States. The states represented were Alabama, Florida, Georgia, Louisiana, New Mexico, North Carolina, Mississippi, Texas and South Carolina. The study included only traditional colleges and universities in those states as well as Historical Black Colleges and Universities (HBCU).

The researcher used Gay's guidelines in this study. Leedy (1985) believes that Gay's guidelines allow the researcher the freedom to select a sample size. Only criminal justice professors who work in institutions that border the southern regional states were used. Using the guidelines allowed the researcher to provide sufficient, specific technical detail regarding how the research took place. The guidelines encourage the researcher to summarize the collected data and determine what aspects of the research need to be strengthened to prevent future problems and how quickly it can be done.

\section{CONCLUSION}

This study was designed to research leadership and managerial decision-making within the DEA by surveying criminal justice professors in the southern border states of the U.S. The preceding chapter presents conclusions, implications, and recommendations for future research that resulted from the findings in this investigation. Information with regard to the demographic variables of respondents plays a significant role in this research.

It has been determined in other studies that the decision making process is sometimes irrational. Clearly, there are alternative consequences strategies available to decision makers. Decision makers who face enormous constraints of time and cost acquire comprehensive information that is impossible to determine in a short constraints (Archer, 1980).

Clearly, leaders all over the world recognize the need for quality decision making. Researchers have also indicated how good leaders utilize various leadership concepts and decision making initiatives to manage an organization and improve its overall effectiveness. By applying various leadership concepts, an effective leader can overcome certain barriers that hinder leadership and decision making; moreover, he or she can deal with organizational challenges that are expected in various situations.

Probably, many of the respondents who participated in this study assume that a manager is limited by his or her own experiences and abilities. However, this way of thinking by leaders must change. Perhaps, developing research to obtain knowledge about each narco-terrorist organization would help every leader or manager reduce mistakes. Leaders who recognize potential mistakes will be successful in avoiding them.

It is argued that decision makers have to take on more responsibility in finding an acceptable or satisfactory solution or seek other action rather than settling for an optimum solution (Simon, 1957). March and Simon (1958) believed there are cognitive limits of rationality; therefore, a lot of decision making by individuals whether it is by them or the organization, should be concerned with satisfactory alternatives, except in cases where it concerns the discovery and selection of optimal alternatives. However, in searching for alternatives, Simon (1957) suggests that one encounters the boundaries of a structure; decision making is based on the formation of alternatives by a well balanced series of searching procedures. 
Those involved in decision making processes have to consider the diversified interests of the participants. It is extremely important to consider the burden of law enforcement leaders who are outside the group or the organization because it is the American people who are the main ones affected. Decision makers have to realize that they are dealing with a conflictual environment and every move should be "adaptively rational" (Hickson, Astley, Butler \& Wilson, 1981). Leaders have to be flexible to adjust leadership techniques depending on whom they are leading. Effective decision making contributes to transformational leadership during periods that call for change or present new opportunities.

In any situation, the process of leadership and decision making stretches beyond the walls of an organization. Leadership starts at the top and having moral character is one the most important traits for making good decisions. The main goal is not to objectively confirm whether it was a good decision but whether it was a decision that everyone can live with for the good of the organization. Making the right choice and making sacrifices for the good of the company is the goal in decision making rather than criticizing those who make the decisions (Hickson, Astley, Butler \& Wilson, 1981).

Although this study sought to determine whether regional location affects decision-making processes of criminal justice professors, it also provided the opportunity to examine the positive and negative ways of leadership from a different perspective. The hope is that this study opens the door for future investigations to explore how academia can influence leadership and other managerial decision-making in governmental entities. Due to the limitations of this study, more research is necessary to further examine how demographics and decision-making among academic experts could have a positive influence within the DEA.

\section{Managerial Implications}

The major objective in this study is to address leadership and decision-making within DEA; however, different concepts of management and the distinct methods used by leadership and management are also clarified.

The scientific concept of management was first introduced by Taylor (1923) who developed four principles of management to demonstrate its overall effectiveness. The first is developing a number of variables for a person's job. Second, there are "out with the old and in with new" required changes in performance. Third, there must be selection, training and development to assist the worker to ensure the work is done correctly. Giving direction allows the leader to clarify his or her objectives and to demonstrate how to achieve short and long-term objectives (Rayburn, 2003).

Fayol (1949) "wrote four functions that managers should utilize in their role which are planning, organizing, leading and controlling." All have to be present if a leader is to be effective. Each function has to complement each other through creative problem solving. Erven (1999) believes "creative problem solving is broader scope to anticipate future problems while problem finding, choice-making or being a decision making limits its ability to see where the problem is coming from." The intended result should be the same which is to achieve the goal and mission.

\section{REFERENCES}

1. Archer, E.R. (1980). How to make a Business Decision: An analysis of theory and practice. Management Review, 69(2), 54-61.

2. $\quad$ Baldoni, J. (2004, Spring). Powerful leadership communication. Leader to Leader. 32(20).

3. Bass, B., Stogdill, R. (1990). From transactional to transformational leadership: Learning to share the vision. Organizational Dynamics, 18(19-31).

4. Clark, D. (1997). Concepts of leadership. Retrieved May 25, 2006 from http://www/nwlink.com/ conclark/leader.leadled.html.

5. Clawson, J. (1996). Level three leadership-getting below the surface. Chapter 5: Six steps to effective leadership. New Jersey: Prentice Hall. 
6. Cohen, S., \& Eimicke, W. (1995) The new effective public manager: Achieving success in a changing government. California: Jossey-Bass Publishers.

7. Cook, R. (2003). 7 formulas for team success. Industrial Management, 45(6), 21.

8. Cox, D. (2001). Leaders are not born. Innovative Leader, 10(10), 1-5.

9. Erven, B. (1999). The Five Functions of Management. Retrieved April 18, 2006 from The Ohio State University Web site: http://extension.osu.edu/ mgtexcel/Function.html

10. Fayol, H. (1949). General and industrial management. London: Sir Isaac Pittman \& Sons.

11. Hickson, D., Astley, W., Butler, R., \& Wilson, D. (1981). Organization as Power. Research in Organizational Behavior, 3, 151-196.

12. House, R. (1996, Fall). Path-goal theory leadership: Lessons, legacy, and a reformulated theory. Leadership Quarterly, 7(3), 323.

13. Hutchinson, A. (2002). Narco-terror: The International connection between drugs and terror. Retrieved March 21, 2006 from United States Department of Justice Web site: http://www.usdoj.gov/dea/speeches/s040202.html

14. Jain, A. (2004) Using the lens of Max Weber's theory of bureaucracy to examine E-government research, in Proceeding of the Thirty-Seventh Annual Hawaii International Conference on Systems Sciences, IEEE Computer Society.

15. Johnson, J. (2002). $11^{\text {th }}$ September, 2001: Will it make a difference to the global anti-money laundering movement? Journal of Money Laundering Control, 6(1), 9.

16. Kennedy, L., \& Lum, C. (2003). Developing a foundation for policy relevant terrorism research in criminology. Prepared for the Center for the Study of Public Security, Rutgers University, Newark, New Jersey.

17. Kleiman, M. (2002). Illicit drugs and the terrorist threat: Causal links and policy implications. Washington D.C: Congressional Research Service.

18. Latemore, G. (2004). The cycle of leadership: How great leaders teach their companies to win. Consulting to Management, 15(3), 58.

19. Leedy, P. (1985). Practical research: Planning and design. (7 $7^{\text {th }}$ ed.). New Jersey: Prentice Hall.

20. March, J.G., \& Simon, H.A. (1958). Organizations. New York: Wiley.

21. Morreale, S. (2000). Law Enforcement Leadership. Doctoral Dissertation, Worcester State College.

22. Rayburn, E. (2003). Principles of management-intensive grazing. Forage Management, West Virginia University, 5828-5831.

23. Stainbrook, M. (2006). The future of law enforcement leadership. Retrieved May 25, 2006 from Police Magazine Web site: http://www.policemag.com/t_leadership.cfm?rank=91324

24. Simon, H. A. (1957). Models of Man, Social and Rational: Mathematical Essays on Rational Human Behavior in Social Setting. New York: Wiley.

25. Tandy, K. (2003). Drugs: Vital speeches of the day, 71(4), 118.

26. Taylor, F. (1923) Scientific management. New York: Harper and Brothers.

27. U.S. Department of the Army (2004). Army leadership field manual. New York: McGraw Hill.

28. Waterman, R. Jr. (1986). The renewal factor. New York: Bantam Books.

29. Weber, M. (1947). Weber's theory of bureaucracy and authority. Retrieved on May 25, 2006 from http://faculty.babson.edu/krollag.org site/encyclop/weber.html 
APPENDIX A

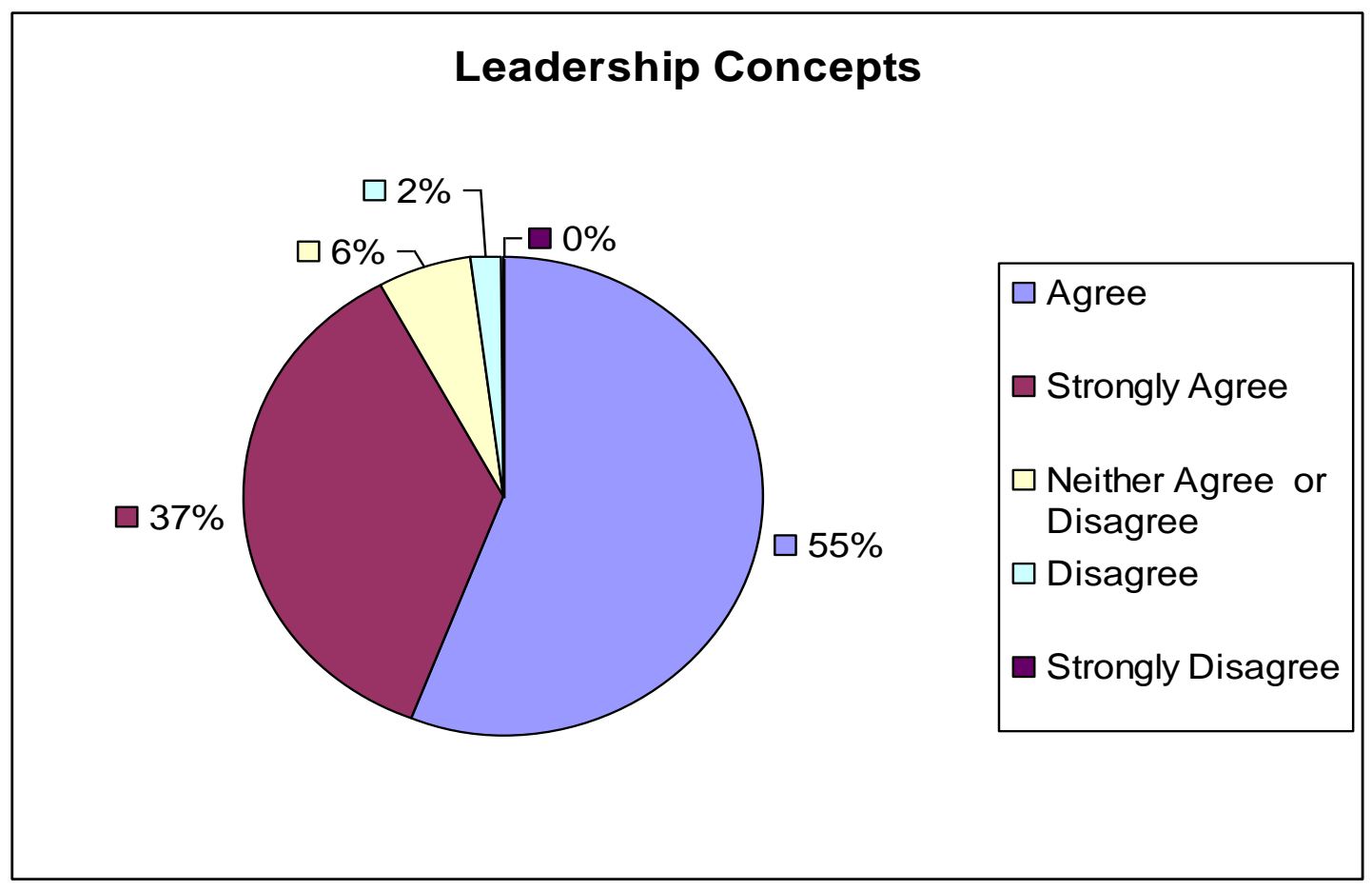

APPENDIX B

\section{Strategic, Organizational \& Managerial Influences}

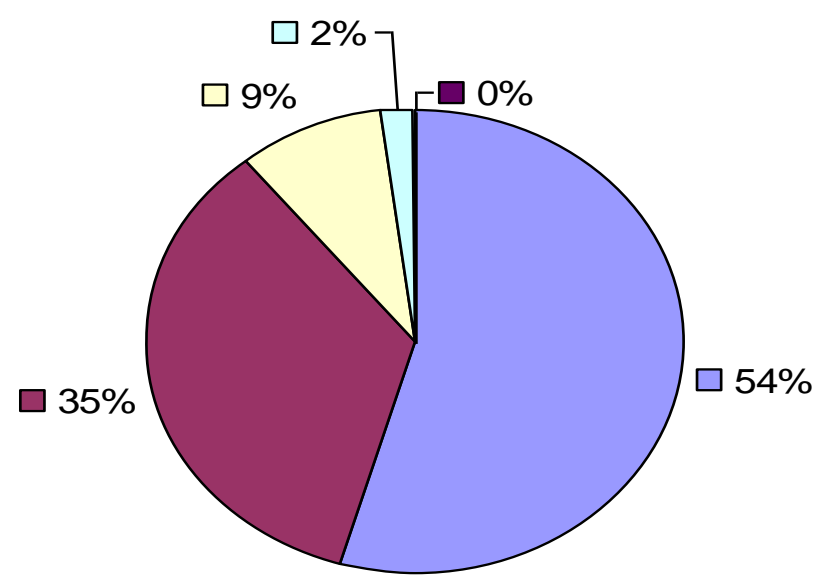

$\square$ Agree

$\square$ Strongly Agree

$\square$ Neither Agree or Disagree

$\square$ Disagree

Strongly Disagree 


\section{APPENDIX C}

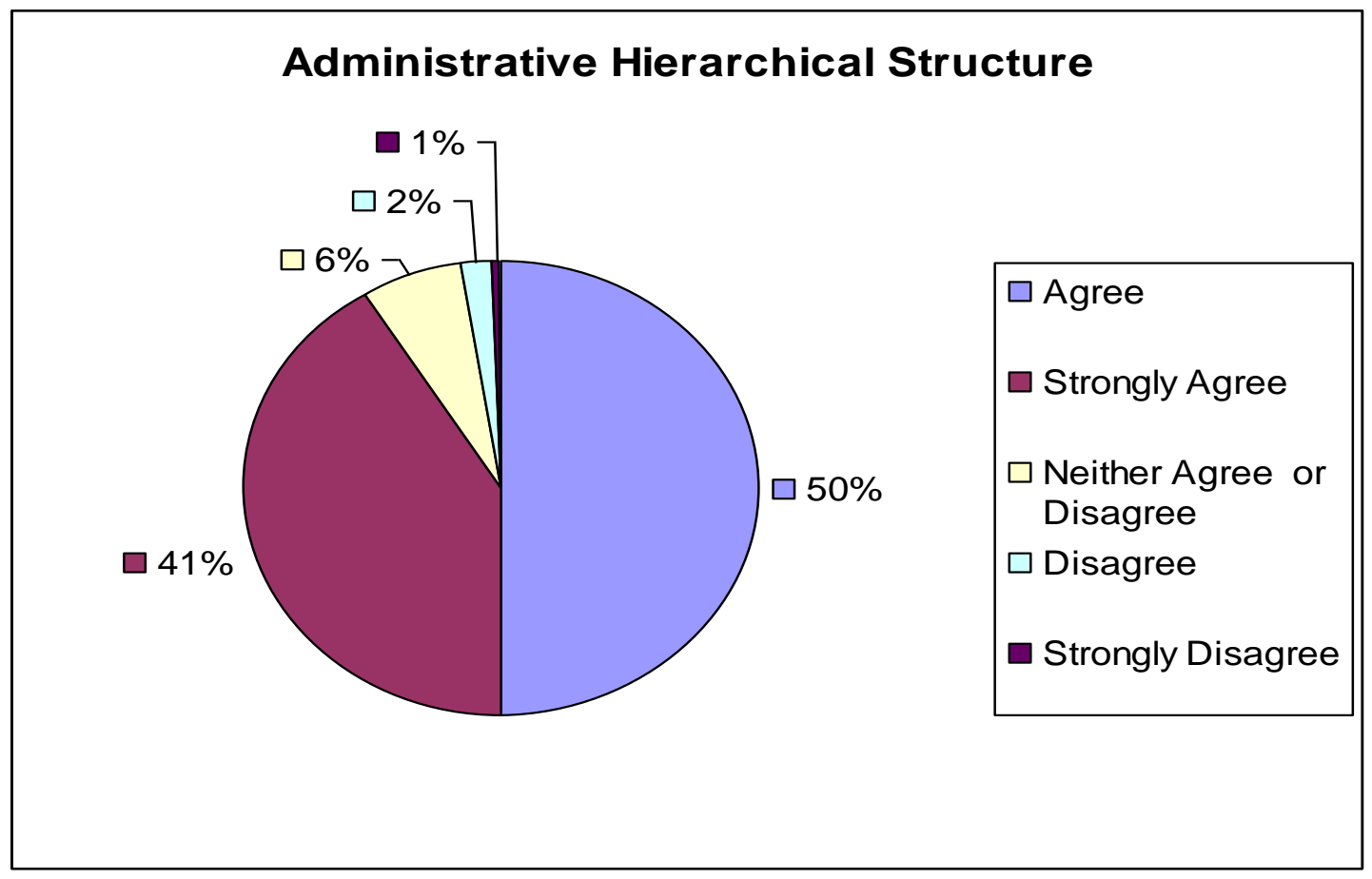

APPENDIX D

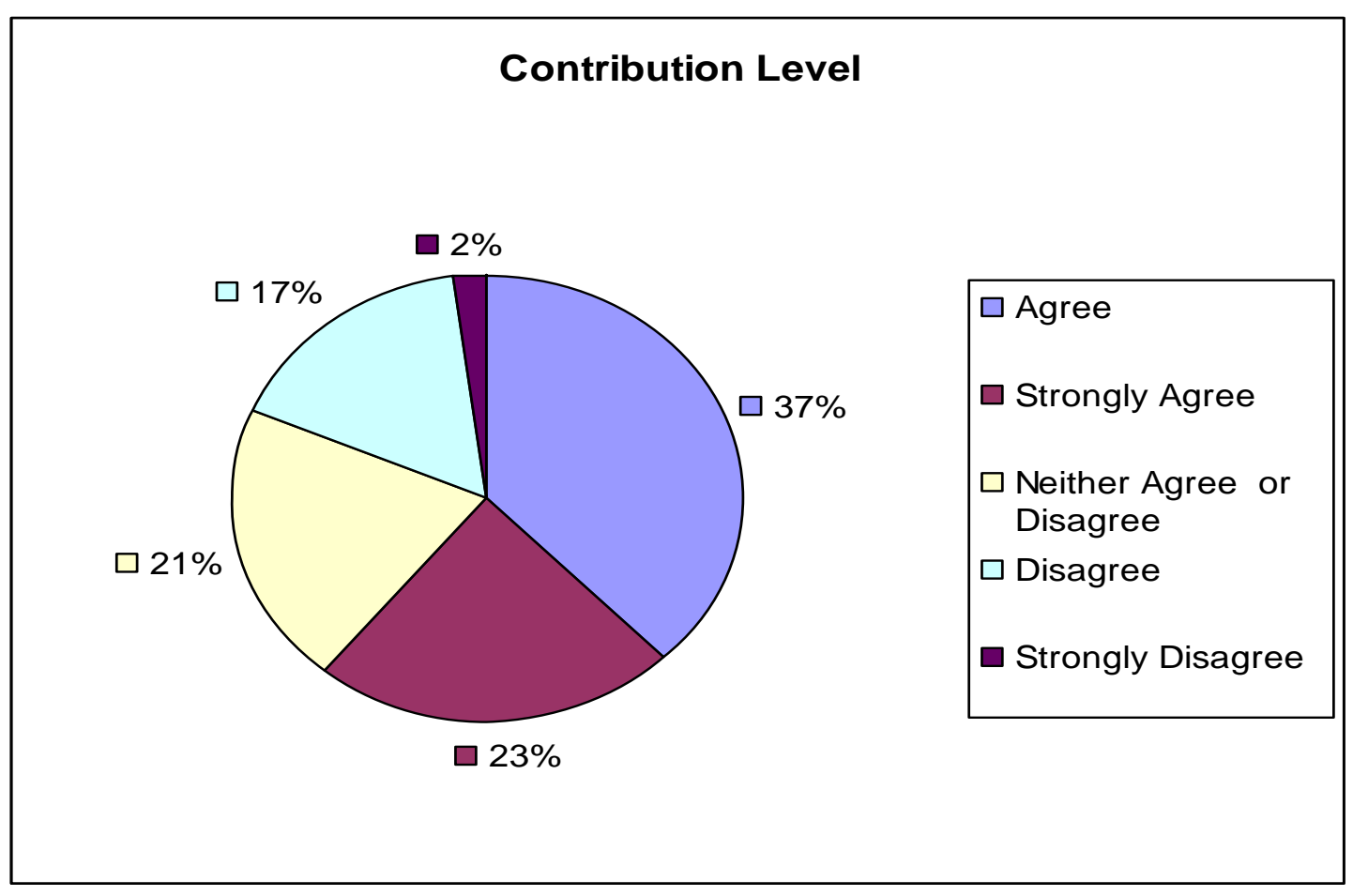


NOTES 